\title{
SURVIVAL OF MAKYUNG IN KELANTAN: THE CHALLENGE UNDER THE FEDERAL CENTRIC ENVIRONMENT
}

\section{(Kelangsungan Makyung di Kelantan: Cabaran di Bawah Pentadbiran Negeri)}

Nurulhuda Adabiah binti Mustafa*

nurulhuda.adabiah@gmail.com

Nuraisyah Chua Abdullah

nuraisyah@uitm.edu.my

Azni Mohd Dian

azni378@uitm.edu.my

Faculty of Law,

UiTM Shah Alam.

Terbit dalam talian (published online): 7 Julai 2020

Sila rujuk: Nurulhuda Adabiah Mustafa, Nuraisyah Chua Abdullah dan Azni Mohd Dian. (2020). Survival of Makyung in Kelantan: The Challenge under the Federal Centric Enviroment. Melayu: Jurnal Antarabangsa Dunia Melayu, 13(2), 253-270.

\begin{abstract}
Makyung is one of the many traditional performances from the Malaysian region that has shaped the Malay national cultural identity. It has been recognized as one of the Masterpieces of the Oral and Intangibles of Humanity in 2001 as well as part of intangible cultural heritage having significant cultural values propounded by the UNESCO International Convention for the Safeguarding of Intangible Cultural Heritage of 2003 (ICH Convention). However, the State of Kelantan had enacted the Entertainment Control and Places of Entertainment Enactment (1998) (KECE 1998) that clearly prohibits any entertainment containing prohibited elements according to Islamic principles. Currently, the performance of makyung was allowed with certain modifications but recently, there is an intention by the state government of Kelantan to prohibit Makyung totally. It is to be noted that there are overlapping powers between the Federal and the State jurisdictions with regard to
\end{abstract}

(C) Dewan Bahasa dan Pustaka. 2020. This work is licensed under the term of the Creative Commons Attribution (CC BY) (http://creative commons.org/licenses/by/4.0/)

ISSN 1675-6460 e-ISSN 2682-8049 
the safeguarding of makyung. At federal level, the National Heritage Act 2005 (the NHA) is the existing law in Malaysia for the safeguarding of intangible cultural heritage inspired by the establishment of the ICH Convention. However, the NHA is a general law that is inadequate at giving comprehensive protection to makyung since heritage matter falls under the Concurrent List of the Ninth Schedule of the Federal Constitution where the State also has the legislative power to make law with regard to the same. In order to address this conflict, there is a need to examine the provisions in the Federal Constitutions, the NHA, KECE 1998 and evaluate to what extent these laws safeguard the performance of makyung. This study examines the conflicts in powers between both Federal and the State Legislations which powers are guaranteed by the Constitution. This study uses the qualitative research method, where a doctrinal research is conducted. This paper contends that, both powers must come to a compromise and meet halfway for the preservation of the heritage.

Keywords: Makyung, federal, state, intangible cultural heritage, law

\begin{abstract}
Abstrak
Makyung merupakan salah satu persembahan tradisional yang telah memperkenalkan identiti kebudayaan kebangsaan Melayu Malaysia di persada antarabangsa. Makyung diiktiraf sebagai salah satu karya lisan kemanusiaan pada tahun 2001 oleh Pertubuhan Pendidikan, Sains dan Kebudayaan Pertubuhan Bangsa-Bangsa Bersatu (UNESCO) kerana persembahan ini mempunyai nilai budaya yang signifikan oleh Konvensyen Antarabangsa Warisan Budaya Tidak Ketara UNESCO (Konvensyen 2003 UNESCO). Walau bagaimanapun, undangundang Negeri Kelantan telah dengan jelas melarang mana-mana hiburan yang mengandungi unsur terlarang mengikut prinsip Islam di bawah Enakmen Kawalan Hiburan dan Tempat Hiburan (1998). Kini, persembahan makyung dibenarkan dengan syarat-syarat tertentu walaupun wujudnya hasrat Kerajaan Negeri Kelantan untuk melarang makyung sepenuhnya. Artikel ini memberikan tumpuan terhadap kuasa bertindih antara Kerajaan Persekutuan dan bidang kuasa Kerajaan Negeri berkenaan dengan pemuliharaan makyung di Negeri Kelantan. Pada peringkat Persekutuan, Akta Warisan Kebangsaan 2005 (NHA) sebagai undang-undang sedia ada melindungi warisan kebudayaan tidak ketara yang diilhamkan oleh Konvesyen Antarabangsa Warisan Tidak Ketara UNESCO. Walau bagaimanapun, NHA sebagai undang-undang am tidak mencukupi untuk memberikan perlindungan komprehensif kepada makyung sejak perkara warisan jatuh di bawah senarai bersama Jadual Kesembilan Perlembagaan Persekutuan, iaitu Negeri juga mempunyai kuasa perundangan untuk membuat undang-undang yang berkaitan dengan perkara ini. Dalam usaha untuk menangani konflik ini, terdapat keperluan untuk menyemak peruntukan dalam Perlembagaan Persekutuan, Akta Warisan Kebangsaan 2005, Enakmen Kawalan Hiburan dan Tempat Hiburan 1998 dan menilai sejauh mana
\end{abstract}


sistem perundangan di Malaysia mampu memelihara seterusnya memulihara makyung sebagai sebuah seni budaya warisan Kebangsaan. Kajian ini mengkaji konflik kuasa antara sistem persekutuan negara dan bidang kuasa negeri yang kuasanya dijamin oleh Perlembagaan. Kajian ini menggunakan kaedah penyelidikan kualitatif, iaitu kajian semula kepustakawanan. Artikel ini menegaskan bahawa kedua-dua kuasa perlukan pengharmonian untuk pemeliharaan warisan.

Kata kunci: Makyung, Persekutuan, Negeri, warisan kebudayaan tidak ketara, undang-undang

\section{INTRODUCTION}

Makyung is one of the many traditional performances from the Malaysian region that has shaped the Malay national cultural identity. It has been recognized as one of the Masterpieces of the Oral and Intangibles of Humanity by United Nation Educational, Scientific and Cultural Organisation (UNESCO) in 2001 as well as part of intangible cultural heritage having significant cultural values recognized by the UNESCO International Convention for the Safeguarding of Intangible Cultural Heritage of 2003 (ICH Convention). However, the evolution of makyung has been in a slow process in Kelantan since the creation of the Entertainment Control and Places of Entertainment Enactment (1998) (the Enactment) by the Kelantan State Assembly. The enactment clearly mentions the prohibition of makyung as one of the entertainment containing prohibited elements according to Islamic principles. Currently, the performance of makyung is still visible in some parts of the region as well as being performed at the National Theatre and part of the curriculum at the National Academy of Arts, Culture and Heritage (ASWARA). However, it is not celebrated in Kelantan itself where makyung was once well-maintained and preserved by State Rulers.

This study examines the conflicts in powers between both Federal and the State Legislations which powers are guaranteed by the Constitution. The laws referred to here are the Federal Constitution and the National Heritage Act of 2005 (NHA 2005) as the federal laws and the Entertainment Control and Places of Entertainment Enactment of 1998 (the enactment) of Kelantan. Since the importance of safeguarding intangible cultural heritage is only obvious to the Malaysian government after the establishment of the ICH Convention, and not during the formation of the 
constitution, the division of powers between the central and state governments in the area of intangible cultural heritage safeguarding is seen as problematic as there is a conflicting and overlapping jurisdiction between federal and states.

\section{MAKYUNG, THE HERITAGE}

"The Ma'yong was introduced into Kelantan from Pattani about 2000 years ago, and continued to be premier palace entertainment until about 1920. Prior to that date groups of Ma'yong actresses were maintained by the Sultan of Kelantan and a number of his relatives. Tengku Temenggung Abdul Ghaffar is stated to have supported one hundred Ma'yong actresses in Kota Bharu in the first decade of the 20th century".

(Sheppard, M., 1969)

Makyung is one of the many traditional performances from the Malaysian region that has been discussed in many literatures such as Sarwar, G. (1976) (2010) (2013) (2016) (2017) and Nasuruddin, M.G. (1986) (1989) (2009). Makyung or referred to as Makyong/Makyong is recognized as a "mystical heritage of Malaysia" and has been awarded as World Heritage (a Masterpiece of the Oral and Intangible Cultural Heritage of Humanity) in 2005 by the United Nations Educational, Scientific and Cultural Organization (UNESCO).

In Malaysia, makyung is recognized as the intangible cultural heritage of the nation. Makyung primadona (main performer) for instance, has been recognized as the living heritage of the nation. This can be illustrated by the designation of Mek Jah binti Deris as the Makyung Primadona by the UNESCO as well as her recognition made by the National Heritage Department of Malaysian as one of the fifteen Living Heritages of Malaysia. The effort was made by the federal government with the purpose of safeguarding Malay identity via Malay traditional performances. Although makyung was suggested as being the most unique and authentic Malay traditional theatre, there are challenges in the preservation efforts. (Utusan Malaysia, 2010) One of the challenges is on the un-Islamic practices in this performance. This article focuses on the essence of conflict which could be addressed from the idea of custodian rights.

\section{INTERNATIONAL RECOGNITION OF MAKYUNG}

The adoption of the ICH Convention on 17 October 2003 marked an important milestone in the United Nations Educational and Scientific Organization's 
(UNESCO) program on cultural heritage. The objective of the ICH Convention is to "safeguard intangible cultural heritage". Scholars have come to a consensus that safeguarding of intangible cultural heritage means measures taken by State party to ensure the viability of intangible cultural heritage within their territory. This would simply means that a State party may adopt its own initiatives and enacts legislation(s) to achieve this purpose through measures geared towards safeguarding intangible cultural heritage within their territory. The term viability can relate to sustainability of intangible cultural heritage which is needed to be inherited or to be passed down from one generation to another. Article 2(3) of the ICH Convention: Safeguarding includes "measures aimed at ensuring the viability of the intangible cultural heritage, including the identification, documentation, research, preservation, protection, promotion, enhancement, transmission, particularly through formal and non-formal education, as well as the revitalization of the various aspects of such heritage."

Makyung has been awarded as World Heritage (a Masterpiece of the Oral and Intangible Cultural Heritage of Humanity in 2005 by the United Nations Educational, Scientific and Cultural Organization (UNESCO). Makyung is documented in various publications with the aim to safeguard its existence. It was also claimed that such publications may form one of the ways to safeguard the performance together with its philosophy and knowledge. Listing is one of the ways in which this traditional performance is safeguarded.

\section{THE NATIONAL HERITAGE ACT 2005}

The NHA was intended to give the responsibilities of preserving, protecting, developing (revitalising) and conserve national heritage to the people. This was also in line with the establishment of Ministry of Culture, Art and Heritage of Malaysia with the objectives of "strengthening the arts, culture and heritage towards enhancing national unity based on the National Cultural Policy; enhancing the synergy and cooperation among the tourism and culture industry players towards making Malaysia the preferred tourist and cultural destinations; strengthening the tourism and culture sectors towards empowering the nation's economy; promoting Malaysia's uniqueness in arts, culture and heritage as the main catalyst for the growth in tourism and culture sectors; and developing knowledgeable, skilled, creative and innovative human capital in tourism and culture sectors" (http://www.motac.gov.my/en/profile/policy).

Makyung is not mentioned in the NHA 2005 because it is a general law. However, literatures contend that makyung is a manifestation falls within the cultural 
expressions domain of the ICH Convention. Within the NHA 2005 itself, the term intangible cultural heritage ( $\mathrm{ICH})$ covers various cultural expressions and these may include makyung. ICH is defined in section 2 of the NHA:

... provides any form of expressions, languages, lingual utterances, sayings, musically produced tunes, notes, audible lyrics, songs, folksongs, oral traditions, poetry, music, dances as produced by the performing arts, theatrical plays, audible compositions of sounds and music, martial arts, that may have existed or exist in relation to the heritage of Malaysia or any part of Malaysia or in relation to the heritage of a Malaysian community.

Before the National Heritage Act 2005 [Act 645] or NHA was gazetted on the 31 st of December 2005 and then enforced on the $1^{\text {st }}$ of March 2006, two main legislation for the conservation and preservation of heritage namely the Malaysian Antiquities Act 1976 [Act 168] (MAA) and the Treasure Trove Act 1957 [Act 542] (TTA). The MAA was intended to deal only with treasure trove, monument, and cultural heritage while the TTA was intended to the discovery of treasure trove. The implementation of the TTA fell under the jurisdiction of the state government. The existence of these laws had been for as long as 29 and 48 years respectively. In fact, the TTA is still relevant for states that do not adopt part XI of the NHA on matters relating to treasure trove.

The Malaysian government had to amend the Federal Constitution in order to facilitate the legislation of the NHA 2005, to include the term "Preservation of Heritage" as the terminology not mentioned in the constitution prior to that. On top of that, the amendment has given both the federal and state government the power to make law pertaining to heritage as provided in Item 9E, List III (concurrent list) of the Ninth Schedule. ${ }^{1}$ The NHA 2005 was intended to give the responsibilities of preserving, protecting, developing (revitalising) and conserve national heritage to the people on top of the federal and state government.

In the parliamentary debate of the NHA Bill in 2005, the NHA was hoped to help strengthen the matter (management) and strengthen the meaning (the effort of defining) of heritage as something having significant value from various aspect, either tangibles or intangibles. However, the parliamentary debate had not touched upon the issue of preserving intangible cultural heritage, either from the minister proposing the bill or other representatives attending the debate. Though it did somehow discuss some issues pertaining to the management of cultural heritage, the absence of debate pertaining to intangible cultural heritage preservation in few 
debates session at the parliament would suggest a bad practise of 'check and balance' where the representatives of the House should already study the bill and consult his people where he is representing. This also suggests that intangible cultural heritage matter was not a matter of importance for the representative to debate on.

The absolute power of the commissioner for heritage was indeed questioned by one of the representatives and the reply was that the ministry and the commissioner has the final say over determining sites (intangible cultural heritage was not mentioned) and that does not mean to suggest that a case cannot be brought to the court of law (a tribunal may be) $)^{2}$. This also suggest that the Minister and the commissioner for heritage (as federal agent/officer) have absolute power of decision-making until and unless the people (as in the case of preserving intangible cultural heritage - holder for heritage/ custodians/ living heritage) is determined enough to challenge the decision of the Minister and the commissioner at the adjudication level. ${ }^{3}$ The minister was not keen to answer the argument of "top-down" approach of making decision by one of the representative illustrates the "bad" practice of "check and balance" in the Malaysian Parliament. A bottom-top approach was suggested; thereby the people, the state government, local councils/authorities, heritage bodies, heritage associations and developer associations (sites) are given the power to be involved in the decisionmaking process. ${ }^{4}$

\section{KELANTAN ENTERTAINMENT CONTROL AND PLACES ENTERTAINMENT ENACTMENT 1998}

With regard to the legislative control, the State of Kelantan, for an instance introduced a law (Kelantan Entertainment Control Enactment) (KECE) of 1998 after PAS won election in 1991 with the aim of achieving the purpose of the Shariah of protecting religion and intellect (from the influence of Buddhism and Hinduism) that was part of the performances themselves. While the state law restricts some of the performances, the NHA 2005 (as the federal law allows the preservation and promotion of any intangible cultural heritage that has cultural significance. This is evidenced in the promotion of makyung at the United Nations of Education, Scientific and Cultural Organisation (UNESCO). ${ }^{5}$ The interference from the Federal Government in the preservation of intangible cultural heritage in the various states is evidenced in every state under the National Heritage Department of each state.

Makyung is mentioned in the Entertainment Control and Places of Entertainment Enactment (1998) (KECE 1998). KECE 1998 however categorized makyung and wayang kulit as prohibited performances (Hiburan Yang Di Larang) at the early state 
of its implementation. ${ }^{6}$ These two performances among others are strictly prohibited compared to another category of controlled entertainment. ${ }^{7}$ This means, licensing authority appointed by the State Authority is not authorised to issue license for these prohibited entertainment at all. ${ }^{8}$ As a consequence, these traditional performances had slowly diminish within the local community and no longer played in rural areas, at least legally. This is the point when preservation of intangible cultural heritage among the local people being taken away until the existence of the $2003 \mathrm{ICH}$ Convention when the international norm recognises the need to preserve traditional performances as part of the intangible cultural heritage.

While the State Government in Kelantan had recently lifted the ban (2019), this however yet to be inserted anywhere in the law. Although the ban had been lifted, it is still within the category of controlled entertainment where the people is not free to play the traditional makyung except the modified version of makyung which would not contrary to the principles of Islam. In other words, while modified version of makyung and wayang kulit have been allowed by the state authority, it is far from being at par with the international norm of intangible cultural heritage preservation. Though there is yet a law that expressly allow the modified version of makyung and wayang kulit to be played in Kelantan, there are guidelines that gives the State Authority to decide. ${ }^{9}$

\section{MODIFICATIONS OF MAKYUNG BY THE FEDERAL GOVERNMENT}

The people who inherit the traditions (individual custodians) refuse to change original characters of the tradition although they have been informed about the change of Kelantan State law with regard to prohibitions of certain elements in makyung. While the Federal Government, under the Ministry of Tourism, Art and Culture promotes the heritage with some modifications to the original characters of the traditions. While preserving makyung, the federal government takes measures of upholding maqasid al-Shariah. Modifications of makyung is one of the federal government's measures to revitalize Malaysians heritage for younger generations. This is how the traditional Gujo-Odori of Japan was revitalized into a more modern approach to suit current moods of the younger generations as well as to meet the educational standards. Bon-Odori has been the modern version from Japan where a culture is preserved for the purpose of awareness and cultural education. 
Regarding to the right of natural justice pertaining to the power of making decision in Malaysia quasi-federal governance, one representative questioned the power of the commissioner who is a decision-maker for any objection of nominations who also play a role in the hearing process cum a final decision maker. ${ }^{10}$ The federal role here seems very dominant and in control over the rights of other parties to get involved in the decision making process, which participation from the "people" is crucial for the safeguarding of intangible cultural heritage. ${ }^{11}$ The role of the commissioner is indeed dominant and this also touches upon the heritage funding. Funding aspect for the safeguarding intangible cultural heritage was not at all mentioned, except for a compensation pertaining to other area of heritage (such as sites and objects other than intangible cultural heritage. ${ }^{12}$

Overlapping powers give so much difficulty in the safeguarding of makyung and wayang kulit in Malaysia. At federal level, the NHA is the existing law in Malaysia for the safeguarding of intangible cultural heritage inspired by the establishment of the ICH Convention. However, the NHA is a general law that is inadequate at giving comprehensive protection to makyung since heritage matter falls under the Concurrent List of the Ninth Schedule of the Federal Constitution where the State also has the legislative power to make law with regard to the same. Generally, heritage matters are governed through powers and jurisdictions of the commissioner for heritage who is appointed under Part III of the NHA. It was emphasized in the parliamentary debate in 2005 that a commissioner for heritage must possess an exemplary knowledge of heritage and always give priority over the strengths and higher values of such heritage..$^{13}$ It was also emphasized in the parliamentary debate that the assistant for the commissioner of heritage must be able to interact with various parties including local councils, representatives from other countries, antiquity experts and any related parties.

In a federal policy such as Malaysia, problems in the distribution of legislative powers are likely to originate in the fact that the central government controls most of the more important and strategic powers, whereas the states are left with less important responsibilities. However less the responsibilities are, the states have to utilize available resources as part of their states legislation. This central bias in the distribution of legislative and executive powers is evident in Articles 71-81 of Part VI of the Federal Constitution, under which the central government is permitted to make laws for the whole or any part of the country; whereas the state assemblies may only make laws for the whole or any part of their own state. ${ }^{14}$ Subject to Article $73,{ }^{15}$ heritage is a matter where both State and the Federal government have power to make law. It should be noted that the head of state is the Sultan/Yang Di Pertuan 
Besar (Negeri Sembilan)/ Yang Di Pertua (Penang)/ Ketua Menteri (Melaka) are Muslims and also the head of Islam.

\section{THE EFFECTS OF FEDERALISM TO MAKYUNG PRESERVATION IN KELANTAN}

Some of the Malay custodians who inherit the traditions have refused to change original characters of the tradition although they have been informed about the change of State law regarding prohibitions of certain elements in makyung. Take for an example Mek Jah binti Deris who believed old traditions must be preserved to safeguard the heritage. However, the Federal Government, under the Ministry of Tourism, Art and Culture promotes the heritage with some modifications where some of the original characters of the traditions are changed to suit the requirement of the state laws. In a way, that is how federal and state government work. Constitutional issues that arises after 1991 Federal election, the federal government has indirectly restricted financial distribution to Kelantan which is currently under the opposition rulings and this has continued until now. ${ }^{16}$ Such refusal to allocate appropriate funds for preserving and safeguarding intangible cultural heritage in Kelantan is an evidence of federalist setbacks occurring in Malaysia and this in turn affect the development of the State of Kelantan as one of the "Cradle of Malay Culture". ${ }^{17}$

However, the Federal Government refuses to allocate a consistent financial assistance and training to the State of Kelantan regarding makyung and other traditional performances even though the State was renowned as the "cradle of Malay culture". Chronologically, constitutional issues that arose after 1991 election, in which the favored Parti Se-Islam Malaysia (PAS) in Kelantan remarked the first in history how the central government under the federalist system (who promotes democracy) mistreated state government. The mistreatment included the matter of preservation and conservation of traditional performances in the State of Kelantan. This is merely because it is the first state ruled by the opposition since the year 1991.

In the case of Kelantan, the study finds that the State Government is having difficulty at assisting the custodians of performance tradition for two main reasons other peripheral reasons. Firstly, the Federal Government refuses to allocate sufficient financial grant for the people to safeguard their intangible cultural heritage, ${ }^{18}$ and secondly, the Kelantan Entertainment State Enactment of 1998 clearly controls the practice of old traditions with the Islamisation of the State by the elected political 
party. Yet, the State Government still allows the practice as long as the people observe the prohibited and the recommended elements in any entertainment. This applies to the old traditions, including Mak Yong and Main Teri. ${ }^{19}$ The federalism system in Malaysia thus gives control of preserving intangible cultural heritage to the federal government and the state government on top of limiting the role of the people who inherit the old traditions from the ancestors.

Federalism was also argued as 'does little to protect the cultural identities and autonomy of minorities' ${ }^{20}$ which then support the idea of qualification and appointment of officers under the NHA 2005 that favors the ruling government under the existing system. The argument was constructed on the basis that the federalist arrangement was made among the Malay leaders as the majority and was contended that the historical arrangement of the federalist system in Malaysia as well as the creation of the NCP of 1971 were made in order to preserve the indigenous claims to sovereignty which is again, contrary to the nature of the Malaysian society; hybrid. While assessing the "minimalist federalism" 21 and semi-democracy in Malaysia, each state which has been given the autonomy to administer their respective territory has certain limitation due to rather strong centralization of the Federal Government. These include budgetary control, legislative control and interferences in the form of "indirect administration" for the benefit of the nation as a whole as well as more importantly for the benefit of the dominant party in terms of its rating in the eyes of public. This indirectly affect the preservation of makyung in Kelantan, of which against the wishes of the State Government itself, thus not been given adequate support from the Federal Government.

\section{THE COMMISSIONER'S ROLE UNDER THE NHA 2005}

The NHA 2005 is the law that somehow or rather, reflecting the intention of the legislature in safeguarding intangible cultural heritage within Malaysian community, inspired by the ICH Convention. However, ironically the specific matter of "intangible cultural heritage" was not debated in depth during the parliamentary debate when the law is passed. Nevertheless, it was hoped that "the Ministry under its Department of Cultural Heritage led by the Commissioner continues to take the necessary measures in ensuring the safeguarding of the intangible cultural heritage in Malaysia". ${ }^{22}$ However, the exclusive jurisdiction given to the commissioner for heritage and the minister in the decision-making process creates a complex scenario of preserving makyung in Kelantan. One such scenario is when an individual custodian is not free 
to decide upon the heritage because most of the decision-making process is left to the Commissioner.

The federal government seems to make relevant effort of safeguarding intangible cultural heritage by trying to adhere to the intention of the ICH Convention (although Malaysia is not a member to the ICH Convention)' and the "ASEAN Declaration of Cultural Heritage 2000" (ASEAN Cultural Heritage Declaration of 2000) where Malaysia is one of the signatories. However, as mentioned earlier, the federal roles are very dominant compared to the roles of the state and the people, which seems counterproductive in reaching the objective of truly safeguarding cultural heritage.

In line with the similar provision, the Commissioner gives advice and coordinates with the local planning authority, the Council and other bodies and entities at all levels for the purpose of safeguarding, promoting and dealing with heritage. ${ }^{23}$ This provision, on one hand, assumes to give the general implication of participation from various bodies or entities to safeguard intangible cultural heritage in Malaysia while, on the other hand, illustrates the scenario of federal control over state power to safeguard intangible cultural heritage within the current federalist system. These functions and power, however, are governed by the Public Authorities Protection Act 1948 so as to provide statutory protection over the roles of the officers in charge of preserving and conserving cultural heritage. ${ }^{24}$

Besides the role of the Minister and Commissioner, the NHA 2005 also recognizes the role of the National Heritage Council (NHC). ${ }^{25}$ The functions of the Council are mainly, to advice the Minister and the Commissioner on all matters relating to heritage, administration and enforcement of laws relating to heritage; and to advice the Minister and the Commissioner on matter referred to it by the Minister or the Commissioner. ${ }^{26}$

These roles are somehow interconnected with participation from minority groups as members are usually come from different cultural background but, final evaluation still rests in the hand of the Commissioner and finally the Minister who decides on policy matter. ${ }^{27}$ The fact that members of the NHC are appointed by the Minister is evidence that illustrates interference of the central government in the administration and management of heritage matters is inevitable.

The NHA mentions that the Commissioner shall come out with conservation plan for the purposes of promoting schemes for the education of, or for practical and financial assistance to, owners and occupiers, and for community involvement in decision making. ${ }^{28}$ The State Authority and Local Planning Authority are involved in the conservation plan, but such involvement is to receive the proposal and advise 
from the Commissioner without mentioning the possibility of the State Authority or the relevant Local Planning Authority to question the proposal by the Commissioner with the advice from the National Heritage Council. ${ }^{29}$

The writer is of the view that current organizational structures on heritage matters is exclusively in the hands of the Federal Government as it signifies the exclusive power of the Commissioner for Heritage as well as the NHC members which work together under the purview of safeguarding intangible cultural heritage for the whole nation.

Various functions of the Commissioner for Heritage as the head of the National Heritage Department as stipulated in the NHA signify the regulator's intention to give exclusive control of safeguarding intangible cultural heritage in the hand of several federal government officers. ${ }^{30}$ There are twelve "statutory functions" 31 and four "statutory powers" 32 of the Commissioner. These functions are manifested in many of the National Heritage Department's efforts to safeguard intangible cultural heritage. ${ }^{33}$ These include the documentation and registration of makyung as the Masterpiece of Oral and the Intangibles of Humanity. ${ }^{34}$ Besides that, various activities and programs are carried out since the creation of the NHA in 2005 for the purpose of achieving the ICH Convention's vision and mission. These are illustrated in the National Heritage Department's vision and mission to enliven the nation's heritage to the world stage. ${ }^{35}$

Commissioner for heritage has the statutory power to "to do all things reasonably necessary for the performance of its duties under the NHA". ${ }^{36}$ Both section 6 and 7 of the NHA give wide authority to the Commissioner in making decisions even to advise the Ministers upon heritage matters. This may somehow creates a gap between what the national government (through the Commissioner's advise) and what the state or local governments think about giving protection of intangible cultural heritage in Malaysia. This may be illustrated through the implementation of the Kelantan Entertainment State Enactment 1998 (KECE) in prohibiting some of the traditional performances among the Muslims while the NHA has no provision prohibiting any cultural expression that is against the principles of Shariah.

\section{CONCLUSION}

Constitutionally, both federal and state governments have power to issue law and policies pertaining to heritage as well as custom and culture. ${ }^{37}$ This constitutional guarantee has in fact caused federal-state conflicts in managing intangible cultural 
heritage as illustrated in Kelantan which is ruled by the opposition party. However, the current organizational structures on heritage matters is exclusively in the hands of the Federal Government as it signifies the exclusive power of the Commissioner for Heritage as well as the NHC members which work together under the purview of safeguarding intangible cultural heritage for the whole nation. Various functions of the Commissioner for Heritage as the head of the National Heritage Department as stipulated in the NHA signify the regulator's intention to give exclusive control of safeguarding intangible cultural heritage in the hand of several federal government officers. ${ }^{38}$ This paper contends that, both powers must come to a compromise and meet halfway for the preservation of the heritage.

\section{NOTES}

1 Constitution (Amendment) Act 2005 Act A1239, Item 4.

2 Fasal 24 of the bill pertaining to the power of commissioner for heritage. See recommendations in chapter 6. Fasal 38 (5) dan 39 (5); compensation of the determination of cultural sites by the commissioner for heritage.

3 Fasal 53 (3) dan juga Fasal 55.

4 Even though intangible cultural heritage aspect was not mentioned in his question, the representative was there to raise the issue which is crucial to the safeguarding of intangible cultural heritage.

5 Mak Yong was promoted by the National Heritage Department, under the Ministry of Tourism, Culture and Heritage (Federal Government) to be listed as one of the Masterpieces of the Oral and Intangible of Humanity in 2001, even though the performance is clearly restricted under the State Law of Kelantan.

6 Guideline 3.1 of the State General Circular No. 4, Year 2003 - Guidelines on Entertainment Control of 2003 (Pekeliling Am Negeri Bilangan 4 Tahun 2003 - Garis Panduan Kawalan Hiburan 2003). "Nama, jenis dan hiburan yang dilarang ialah Mak Yong, Menora, Wayang Kulit (tradisional), Main Puteri, Tinju Siam (Tomoi) dan Pelaga Binatang. Larangan ini meliputi semua peringkat persembahan yang mempunyai unsur-unsur atau ciri-ciri hiburan tersebut.

7 Guideline 3.2 of the State General Circular No. 4, Year 2003 - Guidelines on Entertainment Control of 2003 (Pekeliling Am Negeri Bilangan 4 Tahun 2003 - Garis Panduan Kawalan Hiburan 2003).

8 Guideline 4.2 of the State General Circular No. 4, Year 2003 - Guidelines on Entertainment Control of 2003 (Pekeliling Am Negeri Bilangan 4 Tahun 2003 - Garis Panduan Kawalan Hiburan 2003). "Lesen hanya boleh dikeluarkan bagi jenis hiburan yang dikawal selia sahaja dan tertakluk kepada budi bicara pegawai pelesenan dengan syarat-syarat tertentu. Lesen hiburan hanya boleh dikeluarkan beserta dengan kebenaran tempat hiburan daripada pihak berkuasa tempatan berkaitan dalam tempoh yang ditetapkan." 
9 Guideline 5 of the State General Circular No. 4, Year 2003 - Guidelines on Entertainment Control of 2003 (Pekeliling Am Negeri Bilangan 4 Tahun 2003 - Garis Panduan Kawalan Hiburan 2003).

10 Fasal $27-29$ of the Bill.

11 Chapter 2 had discussed in detail about "people" within Malaysian context.

12 Fasal 38 (5) dan 39 (5)

13 Penyata Rasmi Parlimen, Dewan Rakyat, Parlimen Kesebelas, Penggal Kedua, Mesyuarat Ketiga, Bil. 76, Rabu 7 Disember 2005, Rang Undang-Undang Warisan Kebangsaan 2005, Bacaan Kali Yang Kedua Dan Ketiga.

14 Article 73(b)

15 Item 1, Ninth Schedule of the Federal Constitution

16 Yusoff, M. A. (2001). The politics of Malaysian federalism: The case of Kelantan. Jebat, 28, $1-24$.

17 Kelantan was tagged as "The Cradle of Malay Culture" since before it is ruled by the current political party..

18 Yusoff, M. A. (2001). The Politics of Malaysian Federalism: The case of Kelantan. Jebat, 28, $1-24$.

19 Interview with respondent from Bahagian Penyelidikan dan Pembangunan, Jabatan Agama Islam, Selangor (JAIS) on the 8th August 2016 at $2.30-3.30 \mathrm{pm}$.

20 The minorities are the Chinese and Indians who came to the Malay Peninsula as immigrants. See Case, W. (2007). Semi-democracy and minimalist federalism in Malaysia. Federalism in Asia, 124-143 at p. 127.

21 Case, W. (2007). Semi-democracy and minimalist federalism in Malaysia. Federalism in Asia, 124-143.

22 Section 6 of the NHA 2005.

23 As required under Section 6(h) of the NHA which is in line with paragraph (b) of Article 11, 2003 ICH Convention.

24 National Heritage Act 2005, section 122 'The Public Authorities Protection Act 1948 [Act 198] shall apply to any action, suit, prosecution or proceeding against the Commissioner, Deputy Commissioner, Assistant Commissioners, authorized officers, enforcement officers, any member of the Council or the committee, any member of the staff or agent of the Commissioner or the Council in respect of any act, neglect or default done or committed by it or by him, as the case may be, in such capacity'.

25 National Heritage Act 2005, section 8.

26 However, section 9(2) states that the Minister and the Commissioner shall not be bound to act upon the advice of the Council.

27 This goes back to section 9(2) of the NHA when it says, "the Minister and Commissioner shall not be bound to act upon the advice of the council", so, the fact that members of the NHC are from different cultural backgrounds does not guarantee empowerment of people in revitalising intangible cultural heritage in Malaysia.

28 National Heritage Act 2005, section 46 (1)(c) The Commissioner shall, in consultation with the Council, prepare a conservation management plan for the purposes of promoting schemes 
for the education of, or for practical and financial assistance to, owners and occupiers, and for community involvement in decision making.

29 National Heritage Act 2005, section 46 (2) The Commissioner shall from time to time submit such conservation management plan to the State Authority or the relevant local planning authority, as the case may be, and advise and coordinate with the State Authority or the local planning authority for the implementation of the conservation management plan and its guidelines.

30 The National Heritage Act 2005, section 6.The National Heritage Act 2005, section 6.

31 (a) to determine the designation of sites, registration of objects and underwater cultural heritage; (b) to establish and maintain the Register and to determine and specify the categories of heritage to be listed in the Register; (c) to supervise and oversee the conservation, preservation, restoration, maintenance, promotion, exhibition and accessibility of heritage; National Heritage 19 (d) to promote and facilitate any research relating to heritage; (e) to authorise, monitor and supervise excavations for heritage purposes; (f) to maintain documents relating to any excavation, exploration, finding or search for heritage; $(\mathrm{g})$ to establish and maintain liaison and co-operation with the State Authority in respect of conservation and preservation of heritage matters; $(\mathrm{h}$ ) to advise and co-ordinate with the local planning authority, the Council and other bodies and entities at all levels for the purpose of safeguarding, promoting and dealing with any heritage; (i) to promote and regulate that best standards and practices are applied in the conservation and preservation of heritage; ( $j$ ) to advise the Minister with regard to any matter in respect of conservation and preservation of heritage; $(\mathrm{k})$ to perform such other functions under this Act as the Minister may assign from time to time; and (l) to do all such things as may be incidental to or consequential upon the discharge of his powers and functions.

32 (a) to enter into contracts; (b) to acquire, purchase, take, hold and enjoy movable and immovable property of every description; (c) to convey, assign, surrender, yield up, charge, mortgage, demise, reassign, transfer, or otherwise dispose of, ordeal with any movable or immovable property and any interest in any movable or immovable property, vested in the Commissioner; and (d) to do all things reasonably necessary for the performance of its duties under this Act.

33 The National Heritage Department is responsible for reviving, conserving and maintaining Malaysia's heritage as established in the National Heritage Act 2005.

34 In 2001.

35 "To Empower and Champion Heritage as the Core Identity of the Malaysian People's Legacy".

36 National Heritage Act 2005, Section 7(d).

37 Federal Constitution of Malaysia, Ninth-Schedule, List III, Item 1.

38 The National Heritage Act 2005, section 6. 


\section{REFERENCES}

Abdul Aziz Shuaib \& Folasayo Enoch Olalere. (2013). The Kelantan Traditional Arts As Indicators For Sustainability: An Introduction to Its Genius Loci. Journal of Social Sciences (COES\&RJ-JSS), 2(2), 41-54

Cang, Voltaire Garces. (2007). Defining Intangible Cultural Heritage and Its Stakeholders: The Case of Japan. International Journal of Intangible Heritage, 2, 45-56.

Farok Zakaria. (2011). Khatijah Awang dan Seri Temenggong: Satu Kajian Kes terhadap Keusahawanan Seni. UMK Prints. Accessed on 31.5.2017, retrieved from http:// umkeprints.umk.edu.my/id/eprint/186

Federal Constitution of Malaysia.

Foley, K. Wayang Kelantan: Between Intangible Cultural Heritage And Islam. The ICtM Study Group on perforMInG ArtS of SoutheASt ASIA, 188.

Haque, M. S. (2003). The Role of the State in Managing Ethnic Tensions in Malaysia: A Critical Discourse. American Behavioral Scientist, 47(3), 240-266.

Lixinski, Lucas. (2003). Intangible Cultural Heritage in International Law. OUP Oxford. Madiha Ramlan \& Mohammad Abdul Quayum. (2010). Mapping the History of Malaysian theatre: an interview with Ghulam-Sarwar Yousof. Asiatic, 4(2), 155-168.

Nurulhuda Adabiah Mustafa \& Nuraisyah Chua Abdullah. (2003). Preservation of Cultural Heritage in Malaysia: An Insight of the National Heritage Act 2005. Building The Future of Tourism, 407.

Nasuruddin, M.G. (1986). Kesenian dan Drama Teater dalam Perspektif Tamadun Melayu. Persidangan Antarabangsa Mengenai Tamadun Melayu. Kuala Lumpur.

Nasuruddin, M.G. (1989). Bentuk dan Struktur Teater Melayu Tradisi dan Kesinambungannya Teater Sezaman Kini. Persidangan Antarabangsa Tamadun Melayu (2nd: 15-20 Aug 1989: Kuala Lumpur).

Nasuruddin, M.G. (2009). Teater Tradisional Melayu. Dewan Bahasa dan Pustaka:Kuala Lumpur.

National Heritage Act 2005 (Act no. 645).

Shafii, A.S.H. (2009, July). Management of Commercial Makyung Kelantan (Unpublished). 18th Biennial New Zealand Asian Studies Society International Conference, 6-8 July 2009, Victoria University of Wellington, Wellington, New Zealand.

Sheppard, Mubin. (1969). Ma'Yong, the Malay Dance Drama. Malaysian Society for Asian Studies.

State General Circular No. 4, Year 2003 Guidelines on Entertainment Control of 2003.

Utusan Malaysia. Bajet Kekang Survival Makyung. (2010). Accessed on 19.03.2017 10.58am, retrieved from http://ddms.usim.edu.my:80/jspui/handle/123456789/3698.

Yousof, Ghulam Sarwar. (1976). The Kelantan Mak Yong Dance Theatre: A Study of Performance Structure (Unpublished PhD Thesis). University of Hawai'i at Manoa. 
Yousof, Ghulam Sarwar. (2017). The Mak Yong Dance Theatre as Spiritual Heritage: Some Insights. SPAFA Journal, 1(1), 1-9.

Yousof, Ghulam Sarwar. (2013). Issues in Traditional Malaysian Culture. Trafford Publishing.

Yusoff, M.A. (2001). The Politics of Malaysian Federalism: The Case Of Kelantan. Jebat: Malaysian Journal of History, Politics and Strategic Studies, 28, 1-24.

Tarikh Peroleh (received): 9 Mac 2019

Tarikh Terima (accepted): 6 Julai 2020 